\title{
Social Functions of Traditional Minangkabau Expression: Local Knowledge and Wisdom in Speech
}

\author{
Hasanuddin WS and Emidar \\ Fakultas Bahasa dan Seni \\ Universitas Negeri Padang \\ Padang, Indonesia \\ hasanuddinws@gmail.com
}

\begin{abstract}
This paper contains a discussion of the social function of traditional Minangkabau expressions. The traditional Minangkabau expressions is spoken using the figure of speech language. The use of traditional Minangkabau expressions by speakers of their opponents is a knowledge and local wisdom in speak based on the Minangkabau figure of speech language. The social function of figure of speech speaking using traditional Minangkabau expressions meets the criteria of semiotic language functions, especially semantic equivalence, the function of the recording the fact language, and the function of language as a representative or representational function. Based on the research findings, speak in figure of speech language using traditional Minangkabau expressions, effective for the following: (i) giving a reprimand; (ii) advise; (iii) expressing feelings and thoughts; (iv) influencing the other person; (v) order and or prohibit; (vi) reinforcement; (vii) asking or pleading for something; and (viii) insinuation. These eight categories are referred to as the social function speak in figure of speech using traditional Minangkabau expressions.
\end{abstract}

\section{Keywords: Social Functions, Traditional Minangkabau Expressions, Local Knowledge and Wisdom, Speech}

\section{INTRODUCTION}

In the effort to achieve the goals of national development, efforts to explore, recognize, document, and preserve the positive heritage of the Indonesian ancestor culture need to be done. This can enrich and reinforce the sense of pride of future generations of the nation's precious heritage. In addition, a good introduction to cultural heritage by future generations can reinforce the nation's tradition in responding to the increasingly tough future challenges of this era of globalization.

One of the intangible cultural heritages of the Minangkabau moral-spiritual heritage, obtained and known through the speak in figure of speech using traditional expression. According to Navis (1984: 4), the cultural values of tradition as a type of pronunciation is a system of communication. Human life, and in itself human relations, is dominated over beliefs or beliefs. If it grows and develops, beliefs or beliefs are accepted as truth. Society's belief in something may well be beyond the general logic, but such beliefs according to Barthes (2003: 124) can not be blamed. The thing to be aware of the beliefs of the people is not the question of right or wrong, but the extent to which it functions in fulfilling the social functions of people's lives. Therefore, in conditions where society believes in a tradition's values as truth and that it is believed to enable the emergence of communal solidarity, such a belief can serve as a proposition as science, inherited rules, and practiced by generation, Form of memory and memories, ideas, or decisions that are believed.

The Minangkabau community is one of the strong ethnic and exist in Nusantara. The identity of Minangkabau authenticity has contributed to the form of national culture, among others through language, art, and other aspects of tradition. The people who are strong and able to contribute their culture are strong, compact, and proud of their identity. Such a society grows because it has a "glue." The glue must be of fundamental values that can integrate the Minangkabau society into a unified pattern of life (the views and values of life, and the philosophy of life as a local wisdom in solving the various problems of life) . One of the adhesives used can be said to originate from the traditional values that can be found in the oral tradition of the Minangkabau traditional expressions.

In the right and constructive conditions, traditional values can help the dynamics of people's lives in which those fundamental values live and thrive; Cultivate and develop community integrity, create social solidarity, foster pride in group identity, and be useful to establish communal harmony. Therefore, in essence every society, both traditional society and modern society need the values of life based on belief or belief on certain things to live harmonious living together.

Minangkabau people call his country with Minangkabau Nature and its culture with Minangkabau Tradition. The mention of nature implies that nature is everything to the Minangkabau people. Nature is not just a place to live (live, develop, and die), but also the basic philosophy of life. The community mentions the function of nature with the nature of the mine as the teacher (the nature that lies in making teachers) (see also Navis 1984: 28; Hasanuddin WS 2015b: 199; Bakar 1981: 14).

Speak in figur of speech language as told Minangkabau people to his interlocutor using the traditional Minangkabau expressions, is one of the dominant ways of communicating. Through the traditional Minangkabau expression, Minangkabau speakers can convey the teachings of wisdom to their interlocutors. Through the figur of speech language of Minangkabau 
traditional expression, the speaker can give guidance to the speaker in the form of reprimands, advisory, expressing feelings and thoughts, influencing, enjoining and forbidding, reinforcing intentions, asking for something, and insinuating. In such a case, the traditional Minangkabau expression has shown significantly that figur of speech language has a social function for its speaker community. (See also Danandjaja, 1984, Octavianus, 2012; Fanany and Fanany, 2003; Fanany and Fanany, 2008; Navis, 1984; Burn, 1981; Latief, 2002; Udin, 1993; and Salahuddin, 2015).

Based on the above explanation, the effort to find answers to social functions speak use speech of figur using traditional Minangkabau expressions is important to do. Through the discussion of the results of this study, will be known a number of formulations about the knowledge and local wisdom of Minangkabau people speak in figur of speech using the traditional expressions.

\section{METHOD}

The research on which the article is based is qualitative, research done by not using numbers and statistical data processing, but preferring the researcher's appreciation of the interaction between the concepts being studied empirically. A study conducted with the intent to understand the phenomenon of what is experienced by the subject of research such as behavior, perception, motivation, action, holistically, with a specific context that is natural, and by utilizing scientific methods.।

This study is a research that produces descriptive data in the form of written or oral words of people and behavior that can be observed, depending on the observation on humans, both in the region and in terminology. This research prioritizes the natural setting and is done to present the social world, and its perspectives in the world in terms of concepts, behaviors, perceptions, and human issues being studied.

Data This research is data of social function of oral tradition of traditional expression of Minangkabau proverb based on behavior of speech of owner's society. Data collection is done in two stages. The first stage, the inventory stage through literature studies and recording the oral tradition of traditional Minangkabau proverbs. If the data is spoken directly by the informant, the informant's speech is recorded using a tape recorder. The recordings are transcribed into written form. The result of transcription (subsequent script) is subsequently transliterated (transcended) from the Minangkabau regional language into Indonesian. The second stage is the collection of data on the narrative telling environment and social functions (views and philosophy of life, as well as the living values of the speakers' communities associated with the oral tradition of traditional Minangkabau expreesion) Data on this narrative / story setting is collected through recording, And interviews.

\section{FINDING AND DISCUSSION}

The social function data of traditional Minangkabau expression of proverbs, maxims, mamangan, and pameo are inventoried and classified according to traditional Minangkabau expressions spoken by informants residing in Minangkabau cultural customs and the results of previous research which have been recorded (Iskandar, et al., 1961; Fanany and Fanany, 2003; Fanany and Fanany 2008; and Diana, et al., 2015). The social function to speak in figure of speech using Minangkabau traditional expressions in the language pragmatic perspectives (Jakobson in Teeuw, 2000, Danandjaja, 1984, Halliday, 1985, and Oktavianus, 2015) can be explained as follows: how a tradition is perceived as important by society In a communication system.

The data of the teaching function of the speak in figure of speech language using the Minangkabau traditional expressions in this study can be categorized or grouped into the following categories, namely (a) the social function of speak of the proverb, maxim, mamangan, pameo, and the expression of the correcting teaching guide category; (b) the social function of speak of the proverb, the maxim, mamangan, pameo, and the expression of the advising teaching guide category; (c) social functions speak of the proverb, maxims, mamangan, pameo, and the expression of the expressing thoughts and feelings teaching guide category; (d) the social function of speak of the proverb, maxim, mamangan, pameo, and the expression of the to influence teaching guide category; (e) the social function of speak of the proverb, maxim, mamangan, pameo, and the expression of the instruction enjoin and prohibit teaching guide category; (f) social function of speak of the proverb, maxim, mamangan, pameo, and the expression of the instructional reinforce the intent teaching guide category; (g) social function speak of the proverb, maxim, mamangan, pameo, and the expression of the instruction to ask for something or to request teaching guide category; And (h) social function of the proverb, the maxim, mamangan, pameo, and the expression of the sarcasm teaching guide category. Eight categories of social functions spoken in speak speech of figure using traditional Minangkabau expressions can be explained as the following discussion.

The findings of this study show that the teaching-learning social function using the traditional Minangkabau phrase meets the criteria of semiotic function of language, especially semantic equivalence as stated by Jakobson (in Teeuw, 1984, 2000). Pointing out to use the kias language even though semantically meaning is spoken is an indirect meaning but as Jakobson points out, it is more effective in shaping one's character. Based on these findings it can be assumed that the reference or referral of Minangkabau society in formulating traditional expressions is quite diverse. The most important of these findings from the semantic aspect, the noble counsel in the traditional Minangkabau phrase is a reflection of the reality of the speaker's society. The function of this language according to Crystal (1998) as the function of the recording the fact. Halliday (1985) quoting Buhler states that such a function is a representative function or a representational function. The teaching of speakers using the traditional 
Minangkabau phrase really shows that Minangkabau people instill the values of character education through noble advice based on the foundation of their philosophy of life, the "nature of the mine as a teacher" (the nature that stretches into the teacher).

Based on the categorization of this found social function, it appears so closely the relationship between Minangkabau human beings (the society) to the environment in which they live their lives and lives. Therefore, in conveying the instructional guidance for forming a character or even a critical teaching point for undue behavior, the kias language in the traditional phrase is really their reference to the natural phenomenon of their environment. They always observe the nature around and then make it as a learning experience. The learning experience is structured into noble suggestions as a form of teaching point. The teaching aims are mostly delivered using the kias language. The closeness of the Minangkabau to the nature of his life makes the natural environment as well as a vehicle for learning. This can be understood as a form of local wisdom of the Minangkabau people in interacting with the natural environment. Local wisdom that recognizes that human life is very dependent on the natural environment and therefore humans must always keep the natural environment.

The closeness of the Minangkabau people to the nature and environment (flora, fauna, around humans and members of their relatives, as well as the functioning of the limbs) causes in speech-language use using traditional expressions to warned, exhort, express thoughts and feelings, influence, enjoin and ban, reinforce intent, ask for something or plead, and insinuate them using speak in figur of speech language using traditional expression with reference to nature and the environment. To warned an opponent, they use the following traditional expression, examples (i) Lah tuo pado kakak, lah cadiak pado mamak ("Already older than brother, already clever than uncle"; do not be arrogant); (ii) Arang kareh bak taji, tulang bak kanji ("Loud sound like spurs, bone like kanji flour;" Do not behave arrogantly). To advice them using the following traditional expressions, example (i) Jan bakareh-kareh awak, jan bapalak-palak awak, jan pulo basutan-sutan awak ("Do not harden us, do not dare us, nor our sultans"; Life in the world should not be arrogant even though possessed and rank); (ii) Jan batikai ratak jo dagam, jan manggutia puncak kada urang ("Do not cracked clash with degam, do not scratch people's scabies"; Do not fight but take a step, do not open the disgrace of others). To express their thoughts and feelings using the following traditional expression, example include (i) Apo ka tenggang ambai-ambai, lubang takali ombak datang ("What's the power of the jellyfish, the hole dug up the waves coming "; Failure of a job because of the power of others); (ii) Dek ketek taanjo-anjo, alah gadang tabao-bao, alah tuo tarubah tido, sampai mati jadi parangai ("When small is spoiled, after being carried away, after old age does not change, until death becomes a character "; Unexpected behavior caused by mis-education). To influence them using the following traditional expression, example (i) Buah durian jatuah indak jauah dari batangnyo ("Durian fruits fall not far from the tree "; Pay attention to seeds background to choose a life partner); (ii) Elok diambiak jo etongan, buruak dibuang jo mupakaik ("Well taken with calculations, badly discarded with consensus "; Always be careful and calculating if taking a decision). To order and prohibit them using the following traditional expressions, example (i) Papek dilua runciang di dalam, talunjuak luruih kalingkiang bakaik ("Right outside the pointy inside, the index finger straight pinky "; Do not betray); (ii) Tibo di mato jan dipiciangan, tibo di paruik jan dikampihan ("Up in the eye is not closed, until the stomach is not deflated "; Be firm and fair"; Berlakulah secara tegas dan adil). To reinforce their intentions using the following traditional expression, esample (i) Mancancang balandasan, malompek basitumpu ("Chop up have to baseboard, leaping have to pedestal "; If you want to do something should be based on certain rules); (ii) Gadang buayo di muaro, gadang garundang di kubangan, samuik barajo di liangnyo ("Big crocodiles in the estuary, large tadpole tadpole in a puddle, ants become king in its hole "; Every ruling person looks resilient in his dominion, but when he enters or is in another area or outside his power, that person must submit to power in the area). To request something or beg them to use the following traditional expression, example (i) Tagisia dek ka naiak, tasingguang dek ka turun, awak nan indak mansingajo, anta inyo tagak di janjang ("Shifted time will rise, offended time will come down, we are unintentional, whether he is at the stairs "; Apologies, delivered in public places in general, are not for a particular person); (ii) Gadang ombak caliak ka pasianyo, gadang kayu caliak ka pangkanyo ("Big waves look to the sand, big wood look to the base "; Request that the opponent to speak comprehensively assess, do not judge only from birth alone). To insinuate them using the following traditional expression, example (i) Dapek gadiang batuah, tacampak tanduak kabau mati ("Can be get lucky ivory, thrown dead buffalo horn "; Can be new friends, old friends not remembered again when the old friend had a lot to give help); (ii) Tadorong gajah dek gadiang, talompek harimau dek balangnyo ("Encouraged elephant because the tusk, jumped a tiger because the striped "; Make mistakes without hesitating because they have advantages).

The belief or belief of a particular group of people over a period of time must be understood in terms of the conditions of that community group and the same period. Understanding by different groups of people and different periods of time will not produce meaning, it will even lead to misunderstandings. The research findings of the social function of traditional expression of Minangkabau containing noble suggestions through the meaning of figur of speech can be discussed in at least two of the following interesting points.

First, by hearing and or reading traditional Minangkabau expressions diligently, readers and listeners will acquire cognitive knowledge of the reality as reference material or reference by the Minangkabau traditional genius (local genius) formulator. The traditional expression of Minangkabau that reads, Gadang buayo di muaro, gadang garundang di kubangan, samuik barajo in liangnyo (big crocodiles in estuary, big tadpoles in puddles, ants become kings in the hole), makes the listeners and readers of this Minangkabau traditional expression understand and understand the habitats and behavioral characteristics of the animals mentioned in the traditional expression. Humans must be careful when dealing with or meet with crocodiles in the estuary 
because the estuary is the territory and habitat of crocodile life. Likewise, the information that tadpoles grow in size before becoming an adult frog only needs a puddle area. Rapid rivers or vast lakes are not tadpace habitats. Tadpoles life is only limited to mud. Humans must also understand that in the hole ants are powerful because the hole is the home where they live so that they will fight if their holes are attacked intentionally or not by anybody.

The following traditional Minangkabau phrase, which reads Nan tau di kayu tinggi alang, nan tau di poso-poso ayam, nan tau di kili-kili bantiang ("Who knows with a tall tree is a eagle, who knows with a ligature is a chicken, who knows with a rop is a cow's"), listeners and or readers also become more aware of the reality of these three types of animals. Eagle nest is always at the top of tall timber trees. Thus, it can be understood with content related to the height of the trees and climate, the more eagle birds understand. Likewise with a chicken belt that is always tied by the owner, chicken who understands the rope binding because he is always and associated with it, also sweep the most understand about the rope. Hearing and reading traditional Minangkabau expressions, listeners and readers will also feel cognitively about the characteristics and nature of each categorizing reference. The listener and / or reader will become more aware of the behavior, traits and characteristics of plants, fruits, human beings, members of the relatives, members of the body, and the infinite nature of the universe and the universe. This knowledge will have implications for how humans should behave towards nature and the environment to create a harmonious life.

Secondly, by listening, reading, and trying to understand the reality of environmental phenomena; Listeners and or readers in the next stage will be hooked to analogize the phenomenon of the universe into a conclusion understanding of philosophical values that led to the emergence of awareness or the wisdom of self in understanding life and life. The formulation of philosophical values and self-wisdom is then required to be implemented or implemented in life together or in the community. The meaning of these noble counsels is not directly expressed by the speaker. Speakers use the kias language in the form of a traditional phrase so that the meaning is also an indirect meaning. Speakers of speakers (listeners and / or readers) who formulate the meaning of such noble counsel.

To gain meaning, the reader must be good at interpreting the implied meaning of the traditional phrase he hears or reads. To interpret the implied meaning, the listener and or reading will do the contemplation to understand the essence of what he or she heard and or read. Tunjuk in the form of values of wisdom and noble advice that will be high value and higher if contemplated by the audience or readers who have high intelligence as well. The traditional Minangkabau expression contains the meaning of wisdom. Based on the meaning of wisdom that listeners or readers get science teaching point.

From the speakers, the figure of speech in the form of traditional Minangkabau expression is used for the purpose of doing teaching activity. Teaching can be done in various ways. Based on the research findings, speak the figure of speech language using traditional expressions, effective for the following: (i) giving a reprimand; (ii) advise; (iii) expressing feelings and thoughts; (iv) affecting the other person; (v) order and or prohibit; (vi) reinforcement; (vii) asking or pleading for something; and (viii) insinuation. These eight categories are referred to as the social function of the speak in figure of speech using traditional Minangkabau expressions. This finding is in line with the linguist's thinking on speech acts and language functions.

If the hearer and or reader capture the meaning of the wisdom of the noble counsels contained in the traditional phrase, then the next step will accept it and practice it in everyday life. By understanding the meaning of the traditional Minangkabau expression that sounds Capek kaki ringan tangan, capek kaki indak panaruang ringan tangan indak pamacah ("Fast foot light hand, fast foot instead of fighters, light hand instead of solver "; Deft in acting but full of calculations) will give awareness to the listener and or reader that because of lack of alertness or caution, someone will make a mistake that will be fatal, although the actual action is initially based on good intentions. Recognizing the meaning of this traditional Minangkabau expression, will make the listener and or reader careful in maintaining the behavior and attitude. Be careful in using the body parts of the body that may cause displeasure of others who will cause yourself to experience distress as well. If all this time he has done a bad thing, he will try to fix it. Conversely, if all this time he was always careful before taking action, he will be more confident to always be careful in every behavior act.

Based on the findings of this research, traditional elements, traditional expressions, for example, should be regarded as a communication system that provides messages regarding past rules, ideas, memories, memories, or decisions that are believed. Therefore, as Barthes (2003: 14) says that belief in something (the values of wisdom that are believed to be true) contained in the work of an element of tradition, is not an object, concept, or idea, but a symbol in the form Discourse. Such symbols are not always in written form, but can also be speeches, objects, or certain tools. In today's urban society, the symbol can be in the form of pictures, movies, and others. This element is not an object, but can be represented by objects.

The belief in the truth of the values of wisdom and wisdom will apply universally, but the stimulus of traditional expressions will depend on the social, cultural, and geographical conditions of the community of its owner. A stimulus of traditional Minangkabau expressions is not necessarily acceptable in other societies. However, as universal, it is possible that the values of the teaching wisdom contained in the traditional expression can be accepted by a wider group of people. The belief in it will be stronger if more and more of the facts support it, including stories formed by literary works. Such beliefs may be orally and sustained inheritance, but in cosmopolitan societies it may also be through mass media channels such as newspapers, magazines, television, movies, and social media.

Human life, and in itself human relations, is dominated by beliefs. One's attitude toward something is determined by the conviction that is in him. However, contact and acquaintance with something can generate new beliefs based on existing beliefs. 
It may be different from the previous one and it is possible that the new belief is against the previous conviction. Belief in the values of wisdom teaching point if growing and developing, the values of the teaching wisdom will be accepted as truth. People can not be blamed for their beliefs because no other community groups are harmed, even the belief in those values can be used as a solidarity and integrity of the group. At this stage, the oral tradition of Minangkabau traditional expressions can function as theorem in science.

\section{CONCLUSION}

Traditional values of noble counsel or wisdom-shaped values or wisdom in the traditional Minangkabau phrase, as well as other oral traditions, have various social functions, such as projection systems, as a means of validating paranatas And community institutions, as a means of children's education, and as a tool of coercion and supervisor of the norms of society to always be obeyed. Furthermore, traditional Minangkabau expressions, as well as oral languages in general, are also a means of communication, especially in terms of concrete social controls to criticize a person or a group that has violated the norms of society. To criticize a person using traditional phrases (proverbs, maxims, apologies, and pameos) is more acceptable and more targeted than a direct rebuke. This is because traditional phrases are not individual (impersonal) so that although spoken to a particular person but can not be identified with the person directly. If one feels insinuated by hearing satire through the traditional expression addressed to him, he can not be angry at the one who insinuated him because he is aware that the traditional expression conveyed to him is the legacy of the tradition of the ancestors of his society that has been obeyed. Critics who use traditional expressions in these circumstances are supported by tradition. In this position, tradisilah that role, speakers only apply as a distributor.

Based on these conclusions, it is recommended that universities, local governments and other government agencies should promote research, excavation, and the formulation of the values of the living and growing traditions in the community. This is important because the traditional values at some point are capable of functioning as theorem in science. Universities, local government, and other government agencies, as well as the general public not to neglect and underestimate the verbal tradition that lives and grows in society. Every society, whatever modern society, actually requires a living hand in the form of beliefs and values of wisdom.

\section{References}

Aksa, Yati Haswidi. (1990)."Rubah dan kancil suatu gambaran tatanan dunia: studi bandingan beberapa fabel karya la fontaine dan satjadibrata.“ Dissertation. Jakarta: Fakultas Sastra Universitas Indonesia

Bakar, Jamil, dkk. (1991). Sastra lisan minangkabau. Jakarta: Pusat Pembinaan dan Pengembangan Bahasa.

Bakar, Jamil, dkk. (1979). Kaba minangkabau jilid 1 dan jilid 2. Jakarta Pusat Pembinaan dan Pengembangan Bahasa.

Barthes, Roland. (2003). Mitology. Bandung: Dian Aksara Press.

Cholifah. (2003). "Anafora dan katafora pada wacana dongeng anak serta implikasinya bagi pembelajaran bahasa dan sastra indonesia.” Dissertation. Jakarta: FBS Universitas Negeri Jakarata.

Crystal. (1998). A Dictionary of linguistics and Phonetics. Blackwell Publishers.

Danandjaja, James. (1984). Folklor Indonesia: ilmu gosip, dongeng, dan lain-lain. Jakarta: Grafiti Pers

Fanany, Ismet and Rebecca Fanany. (1984). Four is odd five is even: the cognitive frame work of malay proverb. Kuala Lumpur: Dewan Bahasa dan Pustaka.

Fanany, Ismet and Rebecca Fanany. (2003). Wisdom of the malay proverb. Kuala Lumpur: Dewan Bahasa dan Pustaka.

Halliday, M.A.K. (1985). Language, context and text: aspect of language in a semiotic perspective. Victoria: Deakin University.

Hasanuddin WS. (2015). Transformasi dan produksi sosial teks melalui tanggapan dan penciptaan karya sastra. Bandung: Angkasa

Hasanuddin WS. (2015). "kearifan lokal dalam tradisi lisan kepercayaan rakyat ungkapan larangan tentang kehamilan, masa bayi, dan kanak-kanak masyarakat minangkabau wilayah adat luhak nan tigo" in Jurnal Kembara: Jurnal Ilmu Bahasa, Sastra, dan Pengajarannya Volume 1, No. 2 (pp 198-204) PISSN 2442-7632 EISSN 2442-9287. Malang: Universitas Muhammadiyah Malang.

Hasanuddin WS. (2016). "The intangible cultural heritage of minangkabau traditional expressions: the local wisdom of the society in advising and noble advising" in Jurnal Humanus: Jurnal Ilmiah Ilmu-ilmu Humaniora Volume XV, No. 2 (pp 131-141) PISSN 1410-8062 EISSN 2928-3936. Padang: Pusat kajian Humaniora FBS Universitas Negeri Padang.

Iskandar, Nur Sutan, dkk. (1961). Peribahasa. Jakarta: Balai Pustaka.

Junus, Umar. (1993). Dongeng tentang cerita. Kuala Lumpur: Dewan Bahasa dan Pustaka.

Latief, Ch. N. (2002). Etnis dan adat minangkabau. Bandung: Angkasa.

Navis, A.A. (1984). Alam terkembang jadi guru: adat dan kebudayaan minangkabau. Jakarta: Grafiti Press.

Oktavianus. (2015). Bertutur berkias dalam bahasa minangkabau. Padang: FIB Universitas Andalas.

Rusyana, Yus. (2000). Prosa tradisional: pengertian, klasifikasi, dan teks. Jakarta: Pusat Bahasa

Sunardjo, Nikmah, dkk. (2000). Struktur karya dan nilai budaya. Jakarta: Pusat Bahasa.

Salahuddin, Amar. (2014). Tradisi lisan maondu pojo: senandung menidurkan anak masyarakat kabupaten lima puluh kota sumatera barat. Padang: Suka Bina Press.

Taum, Yoseph Yapi. (2011). Studi sastra lisan: sejarah, teori, metode, dan pendekatannya disertai contoh penerapannya. Yogyakarta: Lamalera.

Teeuw, A. (2000). Sastra dan ilmu sastra: pengantar teori sastra. Jakarta: Pustaka Jaya.

Udin, Syamsuddin. (1993). Seri tradisi lisan nusantara: rebab pesisir selatan malin kundang. Jakarta: Yayasan Obor Indonesia. 